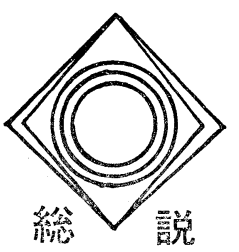

\section{1. はじめに}

アメリカ飞执いては, 従来から石炭が大規模に使用 されて和り，特電力業界では，その50\%近くを石炭 によって発電している。国内産のエネルギー源である 上飞, 国際的な新設火力発電所飞特ける石油使用禁止 のよア゙かけも岕り，将来石炭使用がふえるであうう。 エネルギー省では大統領の政策にそって既設の60基位 を対象化石油から石炭への䎐換命令を今年末迄に出す 予定であるとも報告されている。もともとこれらのボ イシの大部分は, 環境污染が問題となった時に石炭か ら石油へ謓撸したものである。石炭燃燒による排煙中 には，硫黄酸化物，ばいじん，窒素酸化物などが含ま れ大気污染が蛙こる。それを一層きびしく防止するた め昨年 6 月に「新炕設置する施設の有害物質排出 基準」が修正された。

わが国でも，石油の安定供給にかげりが出て来て石 炭の使用が話題にされるよらになった折から, 大気污 染源の一つである亜硫酸ガスに焦点をしはり，アメリ カに频ける排煙脱硫装置の現沉を紹介する。

な怙アメリカに括いては石炭排煙処理が压倒的に多 いため石炭焚を主題としたが，如何なる排煙に対して も脱硫装置としての技術上の大差はない。

\section{2. 新しい排出基集}

アメリカ環境广 (EPA) により発行されている排出 基準 ${ }^{1)}$ は，全体として色々度污染発生源についてそれ ぞれの污染物を対象としている。今回の改正の要点 は, 入力 2 億 5 千万 Btu/時 $(73000 \mathrm{~kW}$ ) 以上の新設発 電用ボイラに㭊る。新設とタイトルに岁るが，改造， 再建を含むと定義されている。

この基準によれば石炭（無煙孷を除く）をるやした 場合, 第 1 図の如き亜硫酸ガス $\left(\mathrm{SO}_{2}\right)$ の除去が必要と なる。入力 100 万 $\mathrm{Btu}$ 当り 12 ポンドの $\mathrm{SO}_{2}$ 学発生する 場合は，90\%の脱硫を行い1.2 ポンドになるよらにし なければならない。るし発生量が 2 ポンドのときは， $70 \%$ 脱硫率で 0.6 ポンドの排出が許される。つまり

*技術開発本部 横浜市神奈川区守屋町3-13
千代田化工建設(株) 野 口 雅 章*

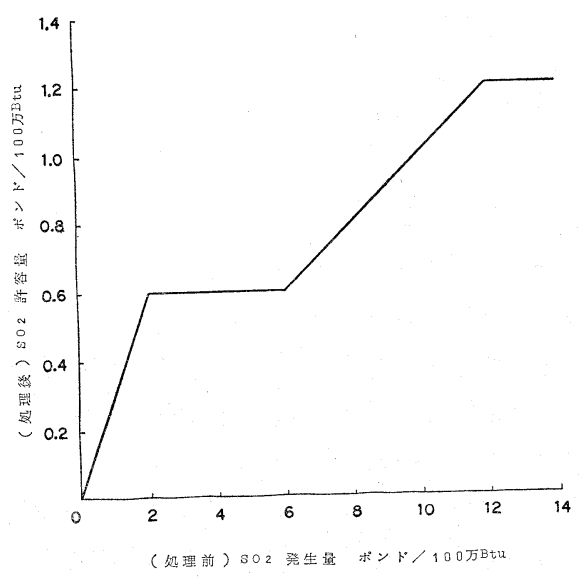

図 1 石炭焚杖

低硫黄炭の場合は低脱硫率で良い。しかしぞんな低硫 黄炭（無煙炭を除く）でも今後何んらかの脱硫を行わ 㸚ばならなくなった。参考のために1ポンド/100万 Btuは約1.8kg/100万キロカロリーに相当する。

脱硫率は每時の平均值を連続30日間炕たって計算 することになっている。EPA はこの基準る決めるに 当り, 国内の排煙脱硫（排脱）装置の実續を統計的飞 処理して, 達成出来るとの裏付けを行った。しかしこ のデータ処理にあやまりがあるのではないかとの疑問 が電力側より出されている2。

\section{3. 排脱装置設嗢状況}

アメリカ国内では, $90 \%$ 近くの石炭は発電用に使用 され残りは工業ボイラ・家庭用等である。78年度総発 電量 ( 2 兆2000意 $\mathrm{kWh}$ ) のらち44.7\% 蝶石炭飞よって

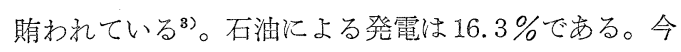
後は石炭と原子力で伸び分を供給して行くものと予想 される。

第 1 表は電力各社に和ける排脱装置の設置状況を李 とめたものである。79年 9 月に EPAが調查しだ) も の最近の情報を加光た。な特小規模のテスト装置は 除外してめる。第 1 表中の燃料は(A)の 3 基合計 180 x 
第1表 電力業界排脱設置状況

\begin{tabular}{|c|c|c|c|c|c|c|c|c|c|}
\hline \multirow{2}{*}{ 方 } & \multirow{2}{*}{ 法 } & \multicolumn{2}{|c|}{ 稼 動 中 } & \multicolumn{2}{|c|}{ 建 設 中 } & \multicolumn{2}{|c|}{ 契 約 済 } & \multicolumn{2}{|c|}{$\overbrace{}^{\text {計 }}$} \\
\hline & & 基 & MW & 基 & MW & 基 & MW & 基 & MW \\
\hline 石 灰 石 法 & & 22 & 7,987 & 18 & 7,438 & 11 & 5,685 & 51 & 21,110 \\
\hline 石＼cjkstart灰＼cjkstart法 & & 26 & 5,957 & 10 & 4,633 & 3 & 1,810 & 39 & 12,400 \\
\hline フライアッシュ混合法 & & 6 & 2,932 & 7 & 2,781 & 1 & 316 & 14 & 6,029 \\
\hline マグネシウム法 & & 1 & 120 & - & - & 3 & 724 & 4 & 844 \\
\hline ダブルアルカリ法 & & 3 & 1,170 & - & - & - & - & 3 & 1,170 \\
\hline 炭酸ソーダ法 & & 3 & 375 & 1 & 550 & - & - & 4 & 925 \\
\hline ウエルマンロード法 & & 3 & 826 & (A) 5 & 1,248 & - & - & 8 & 2,074 \\
\hline $\begin{array}{l}\text { クエン酸法 } \\
\text { スプレードライヤー式 }\end{array}$ & & - & - & 1 & 60 & - & - & 1 & 60 \\
\hline 炭酸ソーダ法 & & - & - & 2 & 540 & - & - & 2 & 540 \\
\hline 石 灰 法 & & - & - & - & - & 2 & 1,040 & 2 & 1,040 \\
\hline 計 & & 64 & 19,367 & 44 & 17,250 & 20 & 9,575 & 128 & 46,192 \\
\hline
\end{tabular}

ガワット（MW）の石油系コークスを除きすべて石炭 である。基はボイラの数であり, 排脱装置の基数では ない。通常電力の場合は予備の一系列があり, 大型ボ イラでは複数の排脱装置を持っている。

第 2 表はデータは古いが, 同じく EPA の発表らり なる電力以外の石炭焚工業用ボイラ用排脱装置のを めである。石炭以外の排湮を処理している装置は, 第 2 表の排煙量の約 6 割める。一般工業の場合, 業種多 岐の上に小型ボイラや燃料以外の $\mathrm{SO}_{2}$ 発生源もあり, 第 2 表が全部をカバーしているか疑問がある。表中に $3220 \mathrm{Nm}^{3}$ /時の排煙量を $1 \mathrm{MW}$ 相当として, 第 1 表と 比較するために記入した。一般工業では基数も少いが 当然のことながら電力に較べて平均規模が小さい。

\section{4. 排脱方法}

排脱の各方法について概略説明する。一般的に湿式 之乾式の 2 方法に大別出来る。乾式法は一時盛んに研
究され建設された。しかし現在運転をたは予定のもの では一方式をのぞいてすべて湿式法である。

\section{1 石灰石法}

石灰石の粉末 (200mesh 以下)を水にあぜてスラリ 一とし，排煙と接触させて $\mathrm{SO}_{2}$ を吸収させる代表的な 湿式排脱法である。 $\mathrm{SO}_{2}$ ほ石灰石のカルシウムと反応 し固体となる。空気による酸化工程を含劣場合は石高 を，含まない場合はそのまま亜硫酸カルシウムのスラ ッジを副生する。これらの固形分は, 沪過されるか, 配管で沈激池に運び, 水は循環使用される。吸收装置 には，スプレー塔とかグリッド棚荅・充填塔などが使 われる。従来石灰石の利用率の悪さや装置の稼動率の 覀さがしばしば問題にされていた。しかし近頃は, 運 転条件一一特に吸收液の $\mathrm{pH}$ - 一設定及びその制御 に注意したり, 酸化工程を組入れたりして改善されて 来ている。更には完全な予備装置を持って何時でも切

第 2 表 一般工業石炭ホホイラ排脱設置状況

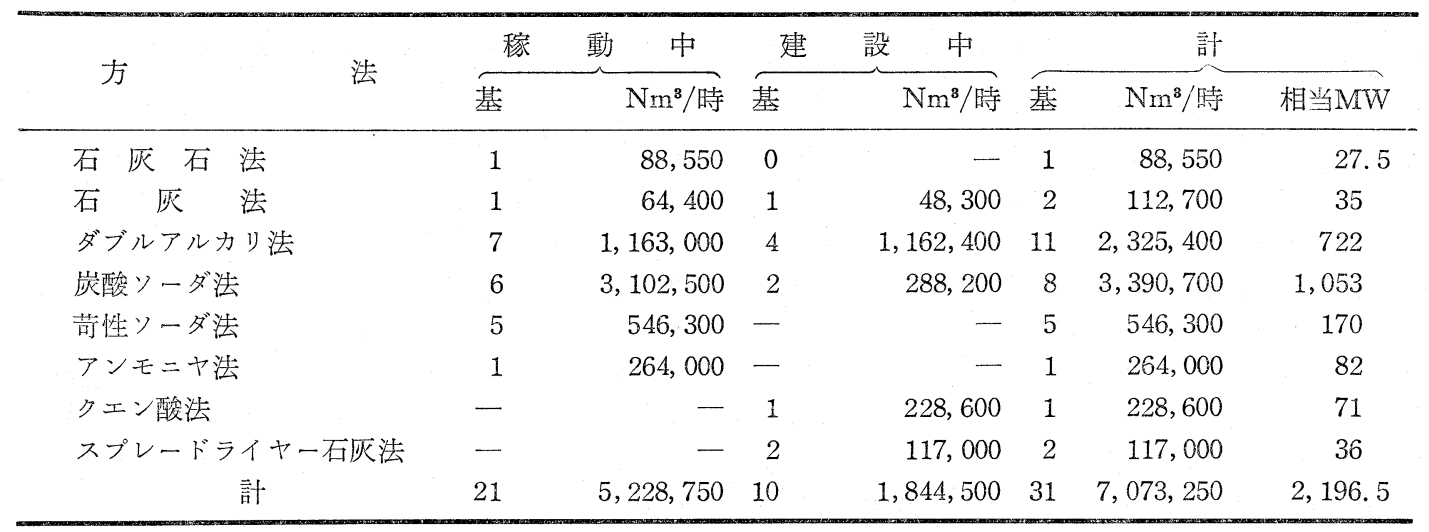


換運転が出来るようにして，全体としての稼動率の向 上をはかっている。稼動率の悪さは装置内での固形物 の沈積やスケールによるものであり，運転をとめて掃 除せざるを得ない。あとに述べる日本の各法は，掃除 頻度が極端に少なく評判が良い。

\section{2 石灰法}

生石灰をスレーキングして前法の石灰石スラリーの 代りに使用する方法である。石灰石に較べて，值段は 高いが，溶解性及び反応性が良く利用率が高いこと， 更にはスケールの傾向が少いといらこと等から排脱の 主流の一つであった。しかし最近は石灰石法に押され 気味である。本法には酸化マグネシウムの添加が有効 であり, 脱硫率が良くなり電力消費が少なくなる。こ のため, 高脱硫率が必要な所や $\mathrm{SO}_{2}$ 含有率の高い所で 実用化されている。

\section{3 フライアッシュ混合法}

アメリカ中央北部やロッキー山脈地带では, 石炭に アルカリ性に富んだ扊分を含んでいる。これを利用し て $\mathrm{SO}_{2}$ を固定する方法であり，不足分は石灰や石灰石 を追加する。

\section{4 マグネシウム法}

石灰法の生石灰の代りに水酸化、グネシウムを使用 する。副生する亜硫酸 マグネシウムを硫酸工場に送 り, 高温飞て熱分解して濃厚 $\mathrm{SO}_{2}$ を発生させ硫酸を作 る。回収したマグネンウムは再使用する。特殊な立地 条件にのみ成立する方法である。

\section{5 ダブルアルカリ法}

石灰・石灰石法などがスケールを起し稼動率が低か ったので本法が開発された。アルカリ（主として炭酸 ソーダ）を供給して $\mathrm{SO}_{2}$ を吸収し，次に石灰にてアル カリ金属を置換して固体を析出させる方法である。排 煙中の残存酸素により，一部のアルカリは石灰による 再生が難しくなり，損失となる。しかしスケールが排 煙の通過する部分に出来にくく運転が容易であるた め, 中小型の一般工業用ボイラに実績が多い。電力用 では76年頃は次代のホープの如く注目されていたが, 今は他の方法の進歩に押され気味である。

4.6 炭酸ソーダ法（苛性ソーダ法他を含む）

ダブルアルカリ法の第一工程のみで, アルカリを再 生循環使用せず廃棄するるのである。中小型の一般用 ボイラに数多く設置されている。ソーダ灰のほかに, 苛性ソーダ, ソーダ廃液などが利用されている。電力 用では天然ソーダ灰を産出する地方に限られて設置さ れている。アンモニ辛使用する方法も研究されてい たが今は中止された。工業的規模では一基のみ砂糖工
場で廃アンモニヤを使用して稼動中である。

4.7 ウエルマンロード法

ダブルアルカリ法の第一工程で $\mathrm{SO}_{2}$ を吸収した液を 加熱により分解し濃厚な $\mathrm{SO}_{2}$ ガスを回収する。硫酸や 硫黄製造浭われるため, これらの工場と隣設してい る必要がある。

\section{8 クエン酸法}

鉱山局が開発した方法である。 $\mathrm{SO}_{2}$ をクエン酸水溶 液て吸収し, 硫化水素を導入して硫黄を副生する。外 部に硫化水素源がない場合, 副生硫黄の3/3を製造 に循環使用せ永ばならない。更に水素源としてメタン 等が必要となる。

\section{9 スプレードライヤー式}

アルカリ性の溶液又はスラリーを排煙中に噴霧す る。水分は蒸発し, $\mathrm{SO}_{2}$ はアルカリ分と反応して固体 となり，灰分と共に集じん装置で補集される。ばいじ ん除去と排脱を兼礼ている。排㖶は水分の蒸発により 若干温度は下るが，まだ充分乾燥して高温であり，そ のまま大気へ放出される。再加熱器が不要で, 乾式排 脱方法の復活とも言うべきものである。アルカリとし てはソーダ灰や石灰を使う。前者の場合值段や入手難 のため, 中小の一般工業ボイラ用であり, 後者の場合 は脱硫率があまり良くないから低硫黄燃料用となる。 また後者の場合, 排出固体分飞かなりの未反応石灰を 含むであうらから，その処理廃棄法を考方ねばならな い。EPA が低硫黄石炭の場合の脱硫率を $70 \%$ にした のは本方式の発達によっている。まだ大型装置で稼動 しているものはない。

\section{5. 今後の動向}

石炭焚ボイラ排脱装置の将来の姿は, 石炭の直接脱 硫や流動床然燒あるいは原子力などの技術の進歩によ ってかわって来るだろう。ここではそのょうな長期の 話はさけ, 最近のいくつかの動きの中から今後の排脱 の方向を示すものを拾ってみた。

\section{1 建設費}

排脱の初期にアメリカでは基礎的なことにあまりカ を払わず，一気体本装置を作っていった。その結果建 設費は実際作ってみるとカタログの 3 倍になることも あった。また建設材料選定のあやまり, ライニングの 失敗, スケール除去のためのぼう大な保守費などによ り，廉価な装置には落し穴があることが解って来た。 法的規制も強められ, 安物を買っておいて「やはり排 脱は動きません」では済まされなくなった。

第 3 表は昨年秋に入札されたアイオワ州マスカティ ン市発電ボイラ用排脱装置の市指定による設計ベース 
第 3 表 マスカティン市発電ボイラ排脱仕様

\begin{tabular}{|c|c|}
\hline 項 目 & 様 \\
\hline 1. 排 煙 量 & $600,000 \mathrm{Nm}^{3} /$ 時 \\
\hline 2. 入口 $\mathrm{SO}_{2}$ & $2,600 \mathrm{ppm}$ \\
\hline 3. 必要脱硫率 & $94 \%$ \\
\hline 4. 原 料 & 石灰石 \\
\hline 5. 副生固形物 & $\begin{array}{l}90 \% \text { 以上酸化されて硫酸塩のこと } \\
20 \% \text { 以の自由附着水 }\end{array}$ \\
\hline 6. 排 & 無排水のこと \\
\hline 7. 建設材料 & 金属使用, 有機ライニングは不可 \\
\hline 8. 系列 & $100 \% 2$ 系列 \\
\hline 9. 見 積 内 & $\begin{array}{l}\text { 石灰石粉哗, 電気集じん機, ブロ } \\
\text { ワ, 排脱装置, 水蒸気使用の再加 } \\
\text { 熱器を含む。 }\end{array}$ \\
\hline 10. 見 積 外 & $\begin{array}{l}\text { 基礎土木工事, 計器・電気室工事, } \\
\text { 煙突工事 }\end{array}$ \\
\hline
\end{tabular}

の要約である。 7 社が応札し, 最低入札と約 800 万ド ルもの差があった第 5 位入札の 会社が 落札した（約 2250 万 \$)。石灰石法のみの応札であり運転経費には 大差はないので，それを达みにしても順位が逆転する ものとは思われない。上位各社には重要な設計ベース に対する除外項目があったり，市側で技術上の難点を 持ったものと思われる。

第 3 表の如く, 本装置は, 石灰石を原料として酸化 工程を含んで拈り，更にライニングを嫌い，100\%の 予備機を要求している。從来の安物買から, 使用者側 の意思が変って来たことを示している。

\section{2 ばいじん除去}

石炭ボイラ排煙は，他の排煙と違い，灰分からのば いじんを多量に含んでいる。普通は排脱装置の前で, 集じん装置により除去されている。湿式装置沉いじ んが多量に入ると閉塞の恐れがある。しかし装置を工 夫すれば，集じん装置の効率を落し，総合的に経済性 をあげることが出来る。副生固形物を廃棄する場 合 は，集じん装置をなくすことも出来る。

\section{3 副生物廃育}

現在, 排脱の副生物は大部分が亜硫酸カルシウムの スラッジであり，沈澱池に，そのままあるいは市販の 固化剤や灰分を加えて捨てられている。

資源保存・回収法といら法律の下で, EPA は有害 廃異物投棄規則を昨年末迄に作ることになっていた。 遅れている模様で呙るが，素案の中に「弱酸性下で有 害ガス・蒸気・煙を発生する亜硫酸塩含有廃亲物は反 応性廃葉物とする」とあり, 廃棄する場合種々の制限 をうけることになる。薬剤による固化を行っても弱酸
によるテストで $\mathrm{SO}_{2}$ を発生すれば対象となる。装置内 に酸化工程を持ち, 硫酸カルシウム即ち石高としてし ま光ばこの規制は受けない。石高は沈降性が良いの で廃棄にあたって水との分離も容易である。また山積 も可能であり, フロリダ州ガルフ電力社内では, 千代 田サラブレッド 121装置からの石膏約 $4000 \mathrm{t}$ を使って 山積の実験が行われた。同装置については後述するが, この約 $400 \mathrm{t}$ の人工石䉰を使って, アメリカでは初め てのボード製造商業テストも行われた。

\section{4 排 水}

石炭中には, 多いもので $0.2 \%$ 以上の塩素を含む場 合がある。燃麻によりガス化し湿式の排脱装置で補集 される。またばいじんや石灰石などから来る可溶性の 不純物も吸收液中に入る。これらの蓄積をさけるため に, 現在多くの装置では, スラッジ沈澱池から排水を 出している。法では排水を出してはいけないとは言っ ていないが，排水を出すには各地方行政府の許可が必 要で，その排水基準に合わ称ばならない。将来規制は きびしくなるものと予想され，クローズドループと呼 ばれる排水なしの装置に向うだろう。この場合吸収液 中の不純物の蓄積による材質上の問題や吸収効率の低 下等を考慮せね齐ばならない。

\section{$5.5 \mathrm{SO}_{2}$ 吸収助剤}

石灰法においてマグネシアの添加が有効であること は先に述べた。多くの排脱方法に有機酸を加光ると効 率が良くなることもわかっている。有機酸としては酢 酸, アジピン酸などが提案されている。分解, 蒸発に よる損失や悪臭を放つ問題があるが，脱硫率の向上や 消費電力の減少とか設備費の割安などから, EPA で は工業的規模でのテストを計画中と言われている。環 境污染がないことがわかれば有望であろう。

\section{6 ブロワの位置}

ボイラの排煙は普通電気集じん装置を通過した後ブ ロワで昇圧され排脱装置に送られ最後に煙突より大気 に放出される。この方がブロワの腐食が少なく経済的 であるからである。

大型ボイラの場合排脱装置はダンパ付ダクトにより 分岐されて複数の系列飞分けられる。京た, 予備系列 も同様にして設置される。頻繁に系を切換えてスケー ル除去や保守を行う必要の岁る装置では, 運転中の系 を少々真空にして蛙けば，修理中の系への漏洩がなく 作業条件が良くなる。このためブロワを排脱装置のあ 之に怙く傾向が目立って来た。保守の大变さから来た 一つの自衛手段であろう。ブロワは, 排煙の再加熱器 をつけたとしても，腐食の傾向は增大して来る。 


\section{6. 日本からの進出}

環境污染の監督官庁である EPA は当然のことなが ら排脱技術の発達, 育成, 情報収集に熱心である。日 本にも多くの調査団を派遣している。また一年半に一 回位の割で, シンポジウムを主催して情報交換の場を 提供している。毎回中央大学安藤教授により日本の排 脱の現況紹介がなされ，大多数の人に関心を持たれて いる。

同シンポジウムでは, 毎回一夜自由討論のパネルが あり, EPA とボイラ所有者側, 所有者とエンジニア リング業界といった間で現実的な議論や意見発表があ り，夫々の裏にかくされた本音が現われて面白い。日 本での排脱装置の稼動率が高かったことに対しては, 運転員の質の良さ，投資金の大きさ，法の簃格さ等々 が理由にされていた。三井アルミ社に設置された装置 と同じ方法の装置がアメリカでらまく作動しなかった ことに対しては, 排水の有無がパネルの話題となった 事もあった。これも無排水であったことがわかり，日 本の技術の確かさが認められて来た。

最近の目立った動きとしては, 第一に三菱重工石灰 石法の進出がある。インデアナ州の電力ボイラに 450 $\mathrm{MW}$ の規模で 2 基建設中である。第一号機の始動は 来年 4 月と予定されている。日本に和いて大型装置で 実証された方法であり，ローカルの条件に合せて設計 は変更されているだろらが，順調に稼動するものと期 待される。

千代田化工は，フロリダ州ガルフ電力会社にて， 76 年よりデモンストレーションをして拉り，最新のサラ ブレッド 121 石灰石・石膏法の10ケ月に亘る運転を昨 年 6 月に終了した。その中の 7 ケ月は EPRI (全米電 力会社の $80 \%$ が出資している電力研究所）の係員立会 のもとに行われ，好結果を特さめた。報告書は，今年 6 月に EPRI より出版予定である。

千代田サラブレッド121法は, JBR（ジェットバブり
ソグリアクター）といら槽に，排湮を吹き达み $\mathrm{SO}_{2}$ を 吸収し，同時に空気を別に吹き达み $\mathrm{SO}_{2}$ を直ちに酸化 する。更にまた，同じ槽に石灰石スラリ一を入れて石 膏を作る。フロリダの装置は, $23 \mathrm{MW}$ 小規模ではあ ったが, ほほ $100 \%$ 稼動率を示した。機器の数が少 く運転が容易な装置である。

次に，同和鉱業の硫酸アルミナ法の進出がめる。同 方法はダブルアルカリ法の第一工程にアルミナを使用 するものである。日本で地道に開発され工業化された 方法で, EPRI のプログラムに組込まれ，TVA（テネ シ一峡谷開発公社）の10MW装置が完成し，昨年秋に 始動した。

TVA ほ古くから 排脱開発の場を提供し，一つの中 心的役割を果している。石灰・石灰石法やアンモニヤ 法, アジピン酸添加方式, クエン酸法などのテスト, 更にはベンチュリ型とかスプレ型の如き装置のテスト を並列行っている。直接比較対照される場所として 最適であり，好結果が期待される。

\section{7. あとがき}

アメリカに拈いて，新設大型の石炭焚ボイラには， 今後かならず何らかの形の $\mathrm{SO}_{2}$ 除去装置がつけられる ことになり，排煙脱硫装置が注目をあびている。その 現況を探り，今後の動向について述べた。個人的興味 や意見に片寄った所も㐫るが，諸先輩に何らかの情報 を提供できれば幸いである。(昭55-2/29)

\section{文献}

1) Federal Register, June 11/1979, p. 33580

2) W.S.Pitts et al., paper presented at 2 nd

Conf. on Air Quality Management Jan. 22-25/1980, Austin, Texas

3) Edison Elec. Inst., Annual Ele. Power Survey, 1979

4) EPA, 600/7-79-022 f, Oct. 1979

5) EPA, 600/7-79-067 b, April. 1979 


\title{
Desulfurization of Coal Burnt Gas in the U.S.A.
}

\author{
Masaaki NoGUCHI
}

(Chiyoda Chemical Engineering \& Construction Co., Ltd.)

SYNOPSIS : - The $\mathrm{SO}_{2}$ emission control of coal burnt gas in the U.S.A. is described with introducing the New Stationary Sources Performance Standard, with summarizing the current $\mathrm{SO}_{2}$ removal processes, and with marking another particular movements. All the new coal burning boilers larger than $250 \mathrm{MMBtu}$ of hourly heat input have to install some kinds of sulfur removal facilities. Limestone scrubbing of the flue gas is the present major technology, followed by lime scrubbing and dual alkali methods in the utilities. Soda ash scrubbing is the major in another industries which are dominated by smaller size boilers. Japanese flue gas desulfurization technologies are also favorably evaluated in the States. 